\title{
Store Choice Behaviour in a Developing Economy: an Empirical Evidence on Household Consumer Durables
}

\author{
Swati Vashishtha ${ }^{1}$, Dr. Sandhir Sharma ${ }^{2}$ \\ ${ }^{1,2}$ (Chitkara Business School/Chitkara University, India)
}

\begin{abstract}
India is an evolving retail destination. Correspondingly the behaviour of the consumer is making new strides as the consumer's metastasis in behaviour brings newer challenges for the retail outlets. The customer has a store choice to make even before he decides on which brand to buy. This study is an attempt to identify, the various dimensions that would drive a consumer to select a store. The study is confined to selected consumer durables as a product category. With focus on the consumer's perception of store selection, 702 respondents were taken into account to arrive at certain store attributes that might be of interest to the large consumer durable industry and the retailers selling these product. Pre-testing followed the result analysis using exploratory factor analysis. The result proposes certain finding relevant for further inquiry on the part of the researchers.
\end{abstract}

Keywords: Consumer durables, factor analysis, retail, store choice.

\section{Introduction}

Retail consumer behaviour remains a widely studied area of research in India (Sinha \& Banerjee, 2004; Srivastava, 2014). The reasons stated are primarily the fact that India is the global destination for companies and is going to remain so for the times to come (KPMG, 2016). Due to continuously changing Indian demographics (PwC, 2015), it had been observed in the recent past that global retail giants have failed to make a mark amongst the Indian consumers. Although the big giants are initiating reforms in customer service, there still remains a gap in understanding the consumer psychology.

The present literature is more centered towards understanding the dynamics of organized retail, which is attributed to the infancy of organized retail in India. To decipher the consumer behaviour for traditional and modern retail (Talreja \& Jain, 2013), it is important that it is explored in light of the developments in the unorganized retail sector in India (Gupta \& Shukla, 2015). The advantage for organized retail seems a disadvantage for the success of a small retail store (Pandey \& Vashisht, 2014). There is disorientation in the preference for the retail store format with respect to the various product categories and the location of the consumer, like towns and cities (ibef, 2016). The researcher after an exhaustive review of the background literature the researcher has made an attempt to understand consumer's store choice for both organized and unorganized store.

The paper is structured to discuss the conceptual framework in the beginning. This is followed by a discussion on the background studies. The methodology of conducting research is mentioned. Lastly the results, analysis, findings have been put forward. The research inquiry ends with a discussion on the limitations and the future purview of the research.

\section{Review of Background Literature}

The review if the past research was done to identify store choice variables for selected household consumer durables. The review also consists of literature concerning different products so as to enable a comparison of store choice amongst various product categories. Table 1 below puts forwards the dimensions and the corresponding researchers supporting the given dimension. The dimensions found were considered to meet the objectives of the study.

Table 1: An overview of various dimensions of store choice

\begin{tabular}{|l|l|}
\hline Authors & Dimensions \\
\hline Purushottam (2011), Thiruvenkadam \& Panchanatham (2015), Singh (2011), & A good bargain on products \\
\hline Mishra, Koul \& Sinha (2014), Thenmozhi \& Dhanapal (2012), Purushottam (2011), & A high quality products \\
Singh (2011), Goswami \& Mishra (2009), Theodoridis \& Priporas (2009), Yilmaz, & \\
Aktas \& Celik (2007), Sinha \& Banerjee (2004), & \\
\hline $\begin{array}{l}\text { Thenmozhi \& Dhanapal (2012), Singh (2011), Goswami \& Mishra (2009), } \\
\text { Backstrom \& Johannson (2006), }\end{array}$ & $\begin{array}{l}\text { Ability of the employees to instill } \\
\text { confidence }\end{array}$ \\
\hline $\begin{array}{l}\text { Mittal, Arora \& Parashar (2011), Narang (2011), Seock (2009), Backstrom \& } \\
\text { Johannson (2006), Paulins \& Geistfeld (2003), }\end{array}$ & An easy layout \\
\hline
\end{tabular}




\begin{tabular}{|c|c|}
\hline $\begin{array}{l}\text { Jaravaza \& Chitando (2013), Thiruvenkadam \& Panchanatham (2015), Mittal, Arora } \\
\text { \& Parashar (2011), Yip, Chan \& Poon (2012), Janakiraman \& Niraj (2011), Seock } \\
\text { (2009), Purushottam (2011), Singh (2011), Goswami \& Mishra (2009), Theodoridis } \\
\text { \& Priporas (2009), Paulins \& Geistfeld (2003), }\end{array}$ & Convenient location of the store. \\
\hline Narang (2011), & Honesty in customer dealing \\
\hline Paulins \& Geistfeld (2003), & $\begin{array}{l}\text { Giving individual attention during the } \\
\text { first visit }\end{array}$ \\
\hline Rigopoulou \& Tsistsou (2008), Yilmaz, Aktas \& Celik (2007), & Easy finance options \\
\hline $\begin{array}{l}\text { Purushottam (2011), Thiruvenkadam \& Panchanatham (2015), Goswami \& Mishra } \\
\text { (2009), Sands, Oppewal \& Beverland (2009), Seock (2009), Rigopoulou \& Tsistsou } \\
\text { (2008), Sinha \& Banerjee (2004), }\end{array}$ & Friendly nature of the employees \\
\hline $\begin{array}{l}\text { Thiruvenkadam \& Panchanatham (2015), Mishra, Koul \& Sinha (2014), Purushottam } \\
\text { (2011), Sands, Oppewal \& Beverland (2009), Yilmaz, Aktas \& Celik (2007), Hundal } \\
\text { (2008), }\end{array}$ & Promotional deals \\
\hline $\begin{array}{l}\text { Thenmozhi \& Dhanapal (2012), Singh (2011), Rigopoulou \& Tsistsou (2008), } \\
\text { Paulins \& Geistfeld (2003), }\end{array}$ & $\begin{array}{l}\text { Giving good quantity of information } \\
\text { to enable decision-making }\end{array}$ \\
\hline $\begin{array}{l}\text { Thiruvenkadam \& Panchanatham (2015), Narang (2011), Purushottam (2011), } \\
\text { Yilmaz, Aktas \& Celik (2007), Paulins \& Geistfeld (2003), }\end{array}$ & Convenient parking facility \\
\hline $\begin{array}{l}\text { Mishra, Koul \& Sinha (2014), Mittal, Arora \& Parashar (2011), Thenmozhi \& } \\
\text { Dhanapal (2012), Purushottam (2011), Singh (2011), Sands, Oppewal \& Beverland } \\
\text { (2009), Theodoridis \& Priporas (2009), Rigopoulou \& Tsistsou (2008), }\end{array}$ & Having wide range of products \\
\hline Narang (2011), Seock (2009), Paulins \& Geistfeld (2003), & Convenient operating hours \\
\hline Thenmozhi \& Dhanapal (2012), & Live product demonstration \\
\hline $\begin{array}{l}\text { Narang (2011), Yilmaz, Aktas \& Celik (2007), Backstrom \& } \\
\text { Johannson (2006), }\end{array}$ & Product knowledge of the employees \\
\hline Paulins \& Geistfeld (2003), & $\begin{array}{l}\text { Giving good quality information to } \\
\text { enable decision-making }\end{array}$ \\
\hline $\begin{array}{l}\text { Mittal, Arora \& Parashar (2011), Narang (2011), Sands, Oppewal \& Beverland } \\
\text { (2009), Theodoridis \& Priporas (2009), Rigopoulou \& Tsistsou (2008), Yilmaz, } \\
\text { Aktas \& Celik (2007), Vyas (2010), }\end{array}$ & Prompt \& time-bound service \\
\hline $\begin{array}{l}\text { Thiruvenkadam \& Panchanatham (2015), Narang (2011), Seock (2009), } \\
\text { Theodoridis\& Priporas (2009), Yilmaz, Aktas \& Celik (2007), Paulins \& Geistfeld } \\
\text { (2003), }\end{array}$ & Store Ambience \\
\hline $\begin{array}{l}\text { Narang (2011), Thiruvenkadam \& Panchanatham (2015), Singh (2011), Seock } \\
\text { (2009), Yilmaz, Aktas \& Celik (2007), }\end{array}$ & The retailers reputation \\
\hline $\begin{array}{l}\text { Narang (2011), Mittal, Arora \& Parashar (2011), Theodoridis \& Priporas 2009), } \\
\text { Rigopoulou \& Tsistsou (2008), }\end{array}$ & Timely delivery and installation \\
\hline Mittal, Arora \& Parashar (2011), Sinha \& Banerjee (2004), & Value for money \\
\hline Thenmozhi \& Dhanapal (2012), Mittal, Arora \& Parashar (2011), & Visual appeal of the store \\
\hline Yilmaz, Aktas \& Celik (2007), & Well groomed employees \\
\hline $\begin{array}{l}\text { Mishra, Koul \& Sinha (2014), Purushottam (2011), Seock (2009), Rigopoulou \& } \\
\text { Tsistsou (2008), Yilmaz, Aktas \& Celik (2007), Paulins \& Geistfeld (2003), }\end{array}$ & $\begin{array}{l}\text { Willingness to handle returns and } \\
\text { exchanges }\end{array}$ \\
\hline $\begin{array}{l}\text { Narang (2011), Rigopoulou \& Tsistsou (2008), Yilmaz, Aktas \& Celik (2007), Sinha } \\
\text { \& Banerjee (2004), Das, Mohanty \& Shil (2008), }\end{array}$ & Good Word of mouth referrals \\
\hline $\begin{array}{l}\text { Purushottam (2011), Thiruvenkadam \& Panchanatham (2015), Rigopoulou \& } \\
\text { Tsistsou (2008), Tripathi \& Sinha (2008), Yilmaz, Aktas \& Celik (2007), Paulins \& } \\
\text { Geistfeld (2003), }\end{array}$ & Retailer's Advertising Effort \\
\hline
\end{tabular}

\section{Analysis And Findings \\ 1.1. Pre-testing}

\section{Methodology}

The research instrument was pre-tested on 55 respondents using convenience sampling. SPSS 21.00 was used to analyze the data. The content validity and the face validity was tested with the help of three academicians in the area of retail and three industry experts who gave their valuable inputs to improve the research instrument. The internal reliability of was determined by using Cronbach's Alpha. The value was 0.847 for all the 27 items taken for the analysis. Based on principal factor analysis 3 items were removed as they had unacceptable factor loadings. The final analysis was based on the remaining 24 items of store choice.

\subsection{Sample characteristics}

The majority of sample belonged to the age group of 26-30 years (37.2\%), followed by $36-45$ years $(23.6 \%)$. A large number of respondents were married (64\%) and mainly belonged to the income segment of INR 30,000 to INR 60,000 (28.9). There were salaried employees $(38.2 \%)$, own business $(20.9 \%)$ and professional $(19.4 \%)$. The education was having majority of graduates $(40.6 \%)$. The number of earning members in the sample was two (45.2\%) and minority had four members earning in the family (6.3\%). The most preferred destination to buy a consumer durable was exclusive brand store $(32.6 \%)$ and the least preferred was online purchase for this segment of products (5.6\%) (Table 2). Due to the nature of the data in descriptive statistics median, mode, skewness or kurtosis was examined for the items used in the questionnaire. There was no need to work on skewness or kurtosis as the data was normal. 
Table 2: Sample profile

\begin{tabular}{|c|c|c|c|c|c|c|c|}
\hline & & Freq & $\mathrm{N} \%$ & & & Freq & $\mathrm{N} \%$ \\
\hline \multirow{6}{*}{ Age } & Less than 18 & 20 & $2.8 \%$ & \multirow{7}{*}{ Occupation } & Professional & 136 & $19.4 \%$ \\
\hline & $19-25$ & 144 & $20.5 \%$ & & Own Business & 147 & $20.9 \%$ \\
\hline & $26-35$ & 261 & $37.2 \%$ & & Salaried Employee & 268 & $38.2 \%$ \\
\hline & $36-45$ & 166 & $23.6 \%$ & & House wife & 80 & $11.4 \%$ \\
\hline & $46-55$ & 78 & $11.1 \%$ & & Retired & 29 & $4.1 \%$ \\
\hline & More than 55 & 33 & $4.7 \%$ & & Unemployed & 12 & $1.7 \%$ \\
\hline \multirow{2}{*}{ Gender } & Male & 478 & $68.1 \%$ & & Student & 30 & $4.3 \%$ \\
\hline & Female & 224 & $31.9 \%$ & \multirow{5}{*}{ Education } & Professional & 108 & $15.4 \%$ \\
\hline \multirow{2}{*}{ Marital Status } & Married & 449 & $64.0 \%$ & & Postgraduate & 200 & $28.5 \%$ \\
\hline & Unmarried & 253 & $36.0 \%$ & & Graduate/Diploma & 285 & $40.6 \%$ \\
\hline \multirow{6}{*}{ Income } & Less than 10000 & 93 & $13.2 \%$ & & 10 th & 74 & $10.5 \%$ \\
\hline & 10000 - 30000 & 185 & $26.4 \%$ & & Below 10th & 35 & $5.0 \%$ \\
\hline & $30000-60000$ & 203 & $28.9 \%$ & \multirow{4}{*}{ Earning Member } & One & 251 & $35.8 \%$ \\
\hline & $60000-100000$ & 112 & $16.0 \%$ & & Two & 317 & $45.2 \%$ \\
\hline & $100000-150000$ & 88 & $12.5 \%$ & & Three & 90 & $12.8 \%$ \\
\hline & More than 150000 & 21 & $3.0 \%$ & & Four or more & 44 & $6.3 \%$ \\
\hline \multirow{7}{*}{ Place of Buying } & Shopping Mall & 106 & $15.1 \%$ & & & & \\
\hline & Exclusive Brand Store & 229 & $32.6 \%$ & & & & \\
\hline & \begin{tabular}{|l|} 
Trade Retail Store \\
\end{tabular} & 201 & $28.6 \%$ & & & & \\
\hline & Wholesale Formats & 78 & $11.1 \%$ & & & & \\
\hline & Stand alone Store & 49 & $7.0 \%$ & & & & \\
\hline & Online & 39 & $5.6 \%$ & & & & \\
\hline & Total & 702 & $100.0 \%$ & & & & \\
\hline
\end{tabular}

\subsection{Analysis for dimensions of store choice}

The analysis was performed on SPSS 21.0. Exploratory factor analysis was applied, after examining whether the data was appropriate for factor analysis or not. The data had significant value of Bartlett's Test of sphericity and the value of KMO was good (0.863) for the application of factor analysis (Table 3). Using 'Kaiser criterion' and varimax rotation, six factors were extracted with variables having Eigen-value greater than 1 .

The first factor was named "Operating policy" where the sub-dimensions explaining were- "Giving good quality of information to enable decision making (0.576), A high quality product (0.576), Giving good quantity of information to enable decision making (0.553), Value for money (0.532), Having a wide range of products (0.521), Retailer's advertising effort (0.473) and Giving individual attention during first visit (0.464) (Table 4). The second importance was given to "Physical appearance" which was explained by- "Well groomed employees (0.708), Visual appeal of the store (0.698), Live product demonstration (0.529) and Store ambience (0.505). The third factor was named "Ease of shopping" with the defined by- "An easy layout $(0.757)$, Convenient location of the store (0.638) and Convenient operating hours (0.613)" (Table 4).

The fourth component was "Customer value" explained by- "Promotional deals (0.736), Easy finance option (0.647) and A good bargain on products (0.547)". The fifth importance was given to "Service" which was explained- "Timely delivery and installation (0.67), Prompt \& time-bound service (0.65), Ability of the employees to instill confidence (0.48) and Willingness to handle returns and exchanges (0.42)" (Table 4). The sixth component was called "Retailer's reputation" explained by- "Good word of mouth referrals $(0.58)$, The retailer's reputation $(0.57)$, Honesty in customer dealing $(-0.44)$ ".

The construct reliability and descriptive statistics for the components has been given in the table 5 .

Table 3: Factor analysis appropriateness for the store choice variables

\begin{tabular}{|c|l|}
\hline Kaiser-Meyer-Olkin Measure of Sampling Adequacy. & .863 \\
Bartlett's Test of Sphericity Chi-Square & 3768.237 \\
\cline { 2 - 2 } p-value Degrees of freedom & 276 \\
& $.0001^{* * * *}$ \\
\hline
\end{tabular}

Table 2: Components of store choice for consumer durables

\begin{tabular}{|l|l|l|l|l|l|l|}
\hline \multirow{2}{*}{} & \multicolumn{5}{|l|}{ Components } & \multicolumn{2}{l|}{} \\
\cline { 2 - 7 } & $\begin{array}{l}\text { 'Operating } \\
\text { policy ' }\end{array}$ & $\begin{array}{l}\text { 'Physical } \\
\text { Appearance' }\end{array}$ & $\begin{array}{l}\text { 'Ease of } \\
\text { shopping' }\end{array}$ & $\begin{array}{l}\text { 'Customer } \\
\text { Value' }\end{array}$ & 'Retailer Reputation' \\
\hline Eigenvalue & 5.70 & 1.70 & 1.38 & 1.33 & 1.16 & 1.08 \\
\hline \% Variance & 23.75 & 7.09 & 5.77 & 5.57 & 4.84 & 4.52 \\
\hline Cronbach's Alpha & 0.72 & 0.73 & 0.75 & 0.78 & 0.73 & 0.72 \\
\hline $\begin{array}{l}\text { Giving good quality information } \\
\text { to enable decision making }\end{array}$ & .581 & & & & & \\
\hline A high quality product & .576 & & & & & \\
\hline
\end{tabular}




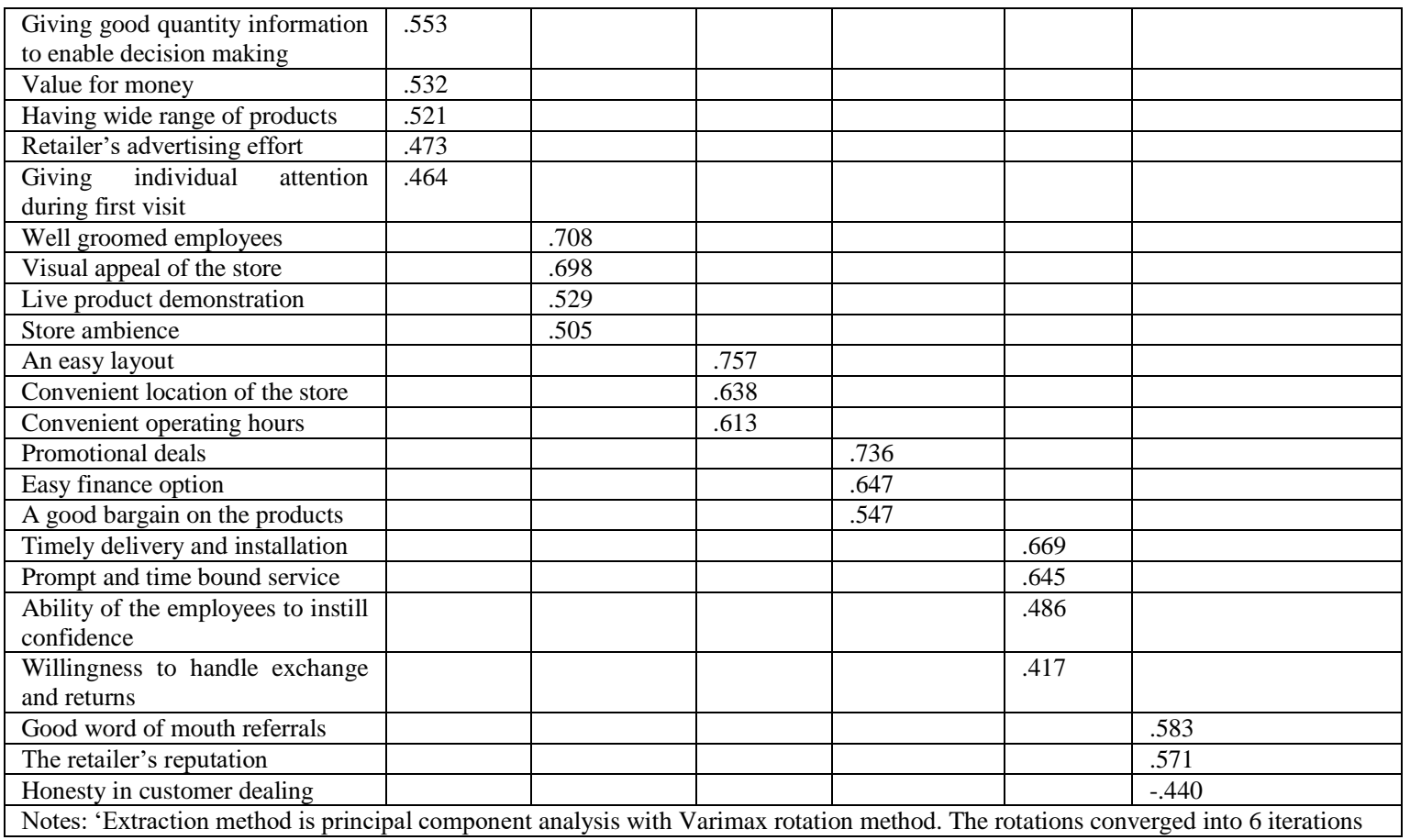

Table 5: Reliability for the factors of store choice

\begin{tabular}{|l|l|l|l|l|}
\hline & $\begin{array}{l}\text { Scale Mean if } \\
\text { Item Deleted }\end{array}$ & $\begin{array}{l}\text { Scale Variance if } \\
\text { Item Deleted }\end{array}$ & $\begin{array}{l}\text { Corrected Item-Total } \\
\text { Correlation }\end{array}$ & $\begin{array}{l}\text { Cronbach's Alpha if } \\
\text { Item Deleted }\end{array}$ \\
\hline Operating Policy & 19.5658 & 5.314 & .607 & .719 \\
\hline Physical Appearance & 19.8774 & 5.100 & .558 & .726 \\
\hline Ease of shopping & 19.8511 & 5.196 & .479 & .747 \\
\hline Customer Value & 19.9631 & 5.264 & .374 & .781 \\
\hline Service & 19.7001 & 5.486 & .547 & .733 \\
\hline Retailer's Reputation & 19.9560 & 4.912 & .594 & .716 \\
\hline
\end{tabular}

\section{Discussion, Findings And Managerial Recommendations}

Similar studies with consumer durable and other product categories were compared to analyze the differences and the similarities in the consumer response. The factors related to service and the information given by the retail were considered important during the purchase of consumer durables indicating that for this product category the service of the retail store and the information given were important as this was an infrequent and high involvement product category (Rogopoul et al., 2008). In a similar study where multiple product categories were studied, it has been reconfirmed that for the consumer durable category strong image of the retailer, retailer's attitude and discounts were important attributes for store choice evaluation. These findings are in line with the results, where retailer's reputation and customer value played an important role in store choice (Mishra et al,. 2014; Singh, 2011; Narang, 2011 Seock, 2009). The convenience that location and other factors like operating hours, parking facility have been considered important by the consumer in any product category, as has been emphasized as ease of shopping as an important factor for store choice (Janakiraman \& Niraj, 2011; Jaravaza \& Chitando, 2013; Purushottam, 2011).

For products like grocery the store choice variables include functional and psychological aspects, where the functional elements were merchandise, price, salesmen, location, and psychological were sales promotion, brand image, atmosphere and reputation (Martineau, 1958; Thiruvenkadam \& Panchanatham, 2015; Mishra et al., 2014; Prashar, 2013; Narang, 2011).

With retail companies expanding with special focus on durables, it becomes imperative for the decision making managers to focus on the factor of having a customer friendly operating policy, focus on the physical aspects of the store, providing convenience of shopping and give the right kind of service. In the longer run the retailer's need to build on building a promising reputation in the market through a good word of mouth with the help of its present customer's. Hence the researcher concludes the discussion by emphasizing on the point that for the consumer durable category a distinctive strategy needs to be framed to get a customer on board.

\section{Limitations And Future Scope Of Research}

The study has geographical limitations and limitation of respondent bias as the data was collected just outside the store and consumer might be influenced by the store just visited. The scope of research lies in 
knowing from the retailer his perception on how he would acquire a new customer and study the gap between the perception of retailer and the consumer. All retail formats could not be studied due to non availability of these formats in the prescribed location. The study can be further expanded to find the segments of consumer and their description so as to better help the decision makers to design the appropriate marketing mix.

\section{References}

[1]. Andrews, D. (2016). Product information and consumer choice confidence in multi-item sales promotion, Journal of Retailing and Consumer Services, 28, 45-53.

[2]. ASA \& Associates LLP, 2015. A brief report on the consumer durable industry in India, available at http://www.asa.in/insights/survey-and-reports/consumer-durables-industry-in-india, accessed on $20^{\text {th }}$ July, 2016.

[3]. Babin, B. J. and Attaway, J. S. (2000). Atmospheric affect as a tool for creating value and gaining share of customer, Journal of Business Research, 49, 91-99.

[4]. Backstrom, K. and Johansson, U. (2006). Creating and consuming experiences in retail store environments: comparing retailer and consumer perspective, Journal of Retailing and Consumer Services, 13, 417-430.

[5]. Banerjee, S. and Singh, P. (2013). Impact of after sales services on consumers buying behaviour for consumer durables: with special reference to air conditioners, International Journal of Applied Services Marketing Perspectives, 2(2), 369-374.

[6]. Bhatia, P. Haider Ali, S. and Mehdi, Z. (2014). A factorial study of consumer buying behaviour towards durable goods with reference to urban working women, International Journal on Recent and Innovation Trends in Computing and Communication, 2(3), 424- 434

[7]. CEAMA, 2015. Study on Indian electronics and consumer durables segment, available at http://www.ey.com/Publication/vwLUAssets/EY-study-on-indian-electronics-and-consumer-durables/\$FILE/EY-study-on-indianelectronics-and-consumer-durables.pdf, accessed on $16^{\text {th }}$ July, 2016.

[8]. Fotheringham, A. S. and Cardiff, U. (1988). Consumer store choice and choice set definition, Marketing Science, 7(3), 299-310.

[9]. Goswami, P. and Mishra, M. S. (2009). Would Indian consumers move from kirana stores to organized retailers when shopping for groceries?, Asia Pacific Journal of Marketing, 21(1), 127-143

[10]. Das B. Mohanty, S. and Chandra Shil, N. (2008). Categorizing consumer buying behaviour: a factor analysis in consumer durable market, International Journal of Business and Management, 3(9),147-156

[11]. Gupta, A. K. and Shukla, A. V. (2015). Store choice behaviour for consumer durables in NCT- Delhi: effect of shopper's demographics, Paradigm, 19(2), 152-169

[12]. Indian Brand Equity Foundation, 2016. Consumer Durables. Retrieved from Indian Brand Equity Foundation Website: www.ibef.org. on 17/05/2016 at $2.30 \mathrm{pm}$.

[13]. Janakiraman, R. and Niraj, R. (2011). The impact of geographic proximity on what to buy, how to buy and where to buy: evidence from high-tech durable goods market, Decision Sciences, 42(4), 889-991.

[14]. Jaravaza, D. C. and Chitando, P. (2013). The Role of Store Location in Influencing Customers' Store Choice, Journal of Emerging Trends in Economics and Management Sciences, 4(30), 302-307.

[15]. Kushwaha, T. (2014). An exploratory study of consumer's perception about relational benefits in retailing, Procedia- Social and Behavioral Sciences, 133, 438-446.

[16]. Louis, D. and Lombart, C. (2011). Image and personality: Two complimentary tools to position and differentiate retailers, International Management Review, 7(1), 66-73.

[17]. Manalel, J. Jose, C. M. and Siby, Z. (2007). Sales promotion-good or bad, International Marketing Conference on Marketing \& Society, 8-10 April, IIMK

[18]. Mishra, H. G., Koul, S. and Sinha, P. K. (2014). Customer perception for store attributes: a study of unorganized retail in India, Business and Economics Journal, 5(4), doi: 10.4172/2151-6219.1000127.

[19]. Mittal, K. C. Arora, M., and Parashar, A. (2011). An empirical study on factors affecting consumer preferences of shopping at organized retail stores in Punjab, KAIM Journal of Management and Research, 3(2), 38-40

[20]. Moye, L. N. and Kincade, D. H. (2003). Shopping orientation segments: exploring differences in store patronage and attitudes towards retail store environments among female apparel consumers, International Journal of Consumer Studies, 27(1), 58-71.

[21]. Narang, R. (2011). Examining the role of various psychographic characteristics in apparel store selection: a study on Indian youth, Young Consumers, 12(2), 133-144.

[22]. Nguyen, B. and Klaus, P. P. (2013). Retailer fairness: Exploring consumer perceptions of fairness towards retailers' marketing tactics, Journal of Retailing and Consumer Services, 20, 311-324.

[23]. Pandey, D. D. and Vashisht, D. A. (2014). Growth of retail in India: assessment of concerns of small retailers, Global Journal of Engineering, Science \& Social Sciences Studies, 3(1), 814-817.

[24]. Paulins, V. A. \& Geistfeld, L. V. (2003). The effect of consumer perceptions of store attributes on apparel store preference, Journal of Fashion Marketing and Management, 7(4), 371-385.

[25]. Prashar, A. (2013). Drivers of store choice in an evolving market: an empirical study, International Journal of Advancements in Research \& Technology, 2(8), 195- 202.

[26]. Purushottam, N. (2011). Store attribute preference in selecting a store: a study of large scale retail stores in South Africa, Journal of Business and Behavioral Sciences, 23(3), 66-81

[27]. PwC, 2015. Destination India 2015- unleashing the prowess, available at http://www.pwc.in/assets/pdfs/publications/2015/pwcdestination-india-2015.pdf, accessed on $18^{\text {th }}$ July, 2016.

[28]. Rai \& Knight Frank, 2016. Think India think retail, Retail Association of India, available at http://www.rai.net.in/images/reports2016/Kight-Frank-think-india-think-retail-2016-3500.pdf, accessed on 14 $4^{\text {th }}$ July, 2016

[29]. Rigopoulou, I. Tsiotsou, R. H. and Kehagias, J. (2008). Shopping orientation-defined segments based on store-choice criteria and satisfaction: an empirical investigation, Journal of Marketing Management, 24(9-10), 979-995. DOI: 10.1362/026725708382000.

[30]. Rogopoulou, I. D. and Tsiotsou, R. H. (2011). Shopping orientation-defined segments based on store-choice criteria and satisfaction: an empirical investigation, Journal of Marketing Management, 24(9), 979-995.

[31]. Seock, Y. (2009). Influence of retail store environmental cues on consumer patronage behaviour across different retail store formats: An empirical analysis of US Hispanic consumer, Journal of Retailing and Consumer Services, 16, 329-339.

[32]. Seock, Y. K. and Bailey, L. R. (2008). The influence of college students' shopping orientations and gender differences on online information searches and purchase behaviours, International Journal of Consumer Studies, 32(2), 113-121.

[33]. Singh, J. (2011). Preference of retailers- a comparison of rural and urban household, Global Journal of Management and Business Research, 11(2), 63-78 
[34]. Talreja, M. and Jain, D. (2013). Changing consumer perceptions towards organized retailing from unorganized retailing- an empirical analysis, International Journal of Marketing, 2(6), 73-85.

[35]. Thenmozi, S. P. and Dhanapal, D. (2012). Store choice behaviour in retail outlets, Global Management Review, 6(2), 10- 23.

[36]. Theodoridis, C. D. and Priporas, C. (2009). Store choice in computer retailing: the case of home users in Greece, EuroMed Journal of Business, 4(1), 58-68.

[37]. Thiruvenkadam, T. and Panchanatham, N. (2015). Store patronage and store choice decision of shoppers, Vishwakarma Business Review, 5(1), 72-78

[38]. Tripathi, S. and Sinha, P. K. (2008). Choice of a retail store and retail store format: a hierarchical model, IIMA, Working Paper No. 2008-04-03.

[39]. Vincent, T. N. (2016). Apparel shopping styles of young adult consumers in Bangalore, Indian Journal of Marketing, 46(2), 50-61

[40]. Visser, E. M. and Du Preez, R. (2001). Apparel shopping orientation: two decades of research, Journal of ecology and consumer sciences, 29(1), 72-81.

[41]. Vyas, H. D. (2010). Consumer purchase of consumer durables: a factorial study, International Journal of Management \& Strategy, $1(1), 1-13$.

[42]. Yilmaz, V. Aktas, C. and Celik, H. E. (2007). Development of a scale for measuring consumer bebahvior in store choice, Social Sciences Journal, 1, 171- 184.

[43]. Yip, C. Y. Y. Chan, K. and Poon, E. (2012). Attributes of young consumers' favorite retail shops: a qualitative study, Journal of Consumer marketing, 29(7), 545-552. 